\title{
UJI KERENTANAN NYAMUK AEDES SP. TERHADAP FOGGING INSEKTISIDA MELATHION 5\% DI WILAYAH KOTA DENPASAR TAHUN 2016
}

\author{
I Wayan Darma Kusuma*, Sang Gede Purnama \\ Alamat: Program Studi Kesehatan Masyarakat Fakultas Kedokteran Universitas Udayana \\ *Email: Kusuma_dark@yahoo.com
}

\begin{abstract}
ABSTRAK
Nyamuk Aedes sp. adalah vektor penyakit Demam Berdarah Dengue (DBD) di Indonesia. Salah satu pengendalian vektor DBD adalah dengan melakukan fogging menggunakan insektisida. Tujuan dari penelitian ini adalah untuk mengetahui tingkat kerentanan nyamuk Aedes sp. terhadap fogging insektisida melathion 5\% di wilayah kota Denpasar sebagai daerah endemis DBD. Penelitian ini merupakan jenis penelitian eksperimental murni dengan rancangan penelitian post-test only with control group design. Jumlah sampel yang digunakan dalam penelitian ini adalah 200 ekor nyamuk dewasa yang dibagi ke dalam kerangka besi masing-masing 25 ekor. Hasil dari penelitian menunjukkan bahwa nyamuk Aedes sp. masih rentan terhadap insektisida melathion dengan konsentrasi 5\% dengan kematian 100\% dalam waktu 60 menit di dalam maupun di luar ruangan rumah. Berdasarkan hasil tersebut dapat disimpulkan bahwa daya bunuh fogging insektisida melathion $5 \%$ terhadap nyamuk Aedes sp. di wilayah Kota Denpasar secara umum masih efektif dan tidak terdapat perbedaan daya bunuh fogging insektisida melathion $5 \%$ terhadap nyamuk Aedes sp. di dalam rumah dengan di luar rumah.

Keywords: Aedes sp, Melathion, Resistensi.
\end{abstract}

\section{ABSTRACT}

Aedes Sp. Is a vector of Dengue Hemorrhagic Fever (DHF) in Indonesia. Among many ways to control DHF, fogging technique using Insecticides is commonly used. The purpose is this study was to determine susceptibility of the Aedes sp. against fogging of $5 \%$ malathion insecticide in the Denpasar city area as a DHF endemic area. This research is a pure experimental research with post-test only with control group design. The number of samples used in this study were 200 adult mosquitoes which were divided into an iron frame of 25 individuals each. The study showed that the Aedes sp. still susceptible to malathion insecticide with a concentration of $5 \%$ with $100 \%$ death within 60 minutes inside and outside the home. Based on the study it can be concluded that fogging technique using 5\% Malathion is effective to kill Aedes Sp. The study also found that there is no difference result of killing power by applying $5 \%$ Malathion inside and outside the house.

Keywords: Aedes Sp., Malathion, Resistance

\section{PENDAHULUAN}

Demam Berdarah Dengue (DBD) masih menjadi masalah kesehatan masyarakat setiap tahunnya di Indonesia. Menurut World Health Organization (WHO) tahun 2010 mencatat Indonesia sebagai negara dengan kasus DBD tertinggi di Asia Tenggara. Penyakit DBD menjadi salah satu masalah kesehatan yang utama di Indonesia terutama di kota-kota besar yang memiliki kepadatan penduduk dan mobilitas tinggi, hal ini dapat dilihat dari kasus DBD yang masih tinggi yaitu Angka kesakitan DBD tahun 2013 tercatat 45,85 per 100.000 penduduk (112.511 kasus) dengan angka kematian sebesar $0,77 \quad \% \quad(871$ kematian), sedangkan pada tahun 2014, sampai pertengahan bulan Desember tercatat penderita DBD di 34 provinsi di Indonesia sebanyak 71.668 orang, dan 641 diantaranya meninggal dunia (Kemenkes RI, 2015).

Salah satu wilayah di Indonesia yang telah endemis DBD adalah Kota Denpasar Bali. Berdasarkan profil kesehatan Dinkes provinsi Bali tahun 2014, pada tahun 2014 jumlah kasus DBD terbanyak adalah di Kota Denpasar yaitu 1.837 kasus dengan 7 orang mengalami kematian dan di tahun 2015 terjadi 1.576 kasus DBD dengan jumlah kematian 14 orang (Dinkes Kota Denpasar, 2015). 
Melihat banyaknya kasus DBD yang terjadi tiap tahunnya, Pemerintah Kota Denpasar telah melakukan berbagai macam pencegahans mulai dari pencegahan secara fisik, biologi maupun kimia. Pecegahan secara kimia dilakukan dengan larvasida dan fogging menggunakan insektisida melathion. Penggunaan bahan kimia dapat memberikan dampak negative yaitu resistensi vektor terhadap insektisida.

Menurut data dasar Program Resistant Pest Management dari Michigan State University, Amerika Serikat, dalam tulisan Shinta (2008) dilaporkan bahwa sampai tahun 2003 Aedes aegypti dari 44 negara telah kebal (resisten) terhadap 16 kelompok bahan kimia dan kekebalan terhadap melathion dilaporkan telah terjadi di 24 negara (Shinta et al., 2008).

Di Indonesia telah banyak dilakukan penelitian mengenai resistensi nyamuk Aedes sp. terhadap melathion. Dari beberapa penelitian tersebut didapatkan hasil bahwa telah terjadi resistensi nyamuk Aedes sp. terhadap insektisida melathion yaitu di daerah istimewa Yogyakarta, Jawa Tengah, 5 wilayah Jakarta dan Bogor (Widiarti et al., 2011 ; Sunaryo et al., 2014 ; Shinta et al., 2008).

Di Indonesia telah banyak dilakukan penelitian mengenai resistensi nyamuk Aedes sp. terhadap melathion. Dari beberapa penelitian tersebut didapatkan hasil bahwa telah terjadi resistensi nyamuk Aedes sp. terhadap insektisida melathion yaitu di daerah istimewa Yogyakarta, Jawa Tengah, 5 wilayah Jakarta dan Bogor (Widiarti et al., 2011 ; Sunaryo et al., 2014 ; Shinta et al., 2008).
Tujuan penelitian ini adalah untuk mengetahui tingkat kerentanan vektor nyamuk Aedes sp. terhadap fogging insektisida melathion 5\%.

\section{METODE}

Penelitian ini merupakan jenis penelitian quasi eksperimental dengan rancangan penelitian post-test only with control group design, dimana dalam penelitian ini nyamuk diberikan intervensi atau perlakuan yaitu disemprot dengan insektisida melathion melalui fogging (pengasapan). Dalam penelitian ini terdapat 2 kelompok perlakuan yaitu kelompok eksperimen dan kelompok kontrol. Kelompok eksperimen diberikan perlakuan (fogging). Penelitian diulang sebanyak tiga kali. Sedangkan kelompok kontrol tidak diberikan perlakuan.

Jumlah sampel yang dibutuhkan dalam penelitian ini adalah 200 ekor nyamuk Aedes sp. dewasa dengan perhitungan sebagai berikut : 100 ekor nyamuk di dalam ruangan +100 ekor nyamuk di luar ruangan $=200$ ekor nyamuk. Dari 100 ekor nyamuk yang ada di dalam dan di luar ruangan dibagi menjadi empat bagian yaitu 25 nyamuk kontrol $(\mathrm{K})+25$ Nyamuk ulangan 1 (U1) + 25 Nyamuk ulangan 2 (U2) + Nyamuk ulangan 3 (U3) .

Penelitian ini dilakukan di wilayah Denpasar, dimana pengambilan sampel atau telur nyamuk dilakukan di 4 Kecamatan Denpasar, pembiakan telur nyamuk dilakukan di Laboratorium Kesehatan Masyarakat Fakultas Kedokteran Universitas Udayana dan perlakuan (fogging) dilakukan di jalan Palapa IV Blok B pada tanggal 4 Mei 2016. 
Pengamatan nyamuk setelah kematian nyamuk $\geq 98 \%$ maka nyamuk diberikan perlakuan akan dilakukan dikatakan rentan terhadap insektisida sebanyak 2 kali yaitu 1 jam pertama setelah perlakuan dan 24 jam setelah perlakuan. Pada saat pengamatan apabila kematian pada kelompok nyamuk kontrol $>20 \%$ maka perlu dilakukan penelitian ulang, sedangkan apabila kematian pada kelompok nyamuk kontrol $<5 \%$ maka dapat diabaikan. Namun apabila kematian pada kelompok nyamuk kontrol yaitu 5\% - 20\% maka harus dilakukan koreksi dengan rumus formula abbot. Interpretasi dari hasil uji kerentanan nyamuk berdasarkan presentase kematian nyamuk setelah diberikan perlakuan dapat dibagi menjadi tiga kelompok yaitu apabila tersebut, apabila kematian nyamuk 80-98\% maka nyamuk dikatakan toleran terhadap insektisida tersebut, dan apabila kematian nyamuk < 80\% maka nyamuk dikatakan kebal (resisten) terhadap insektisida tersebut (Bento et al., 2003).

\section{HASIL}

Pemeriksaan jentik dan tempat-tempat penampungan air dilakukan di 4 Kecamatan di Wilayah Kota Denpasar.

\section{Tabel 1. Frekuensi Rumah yang Diperiksa dan Rumah yang Ditemukan Jentik Di Denpasar (April 2016)}

\begin{tabular}{llccc}
\hline No & Lokasi Pengamatan & Jumlah Rumah & Jumlah & Persentase Rumah \\
& & Diperiksa & Rumah Positif & Positif \\
& & & Jentik & \\
\hline 1 & Denpasar Barat & 50.402 & 1.713 & $3,39 \%$ \\
2 & Denpasar Utara & 49.204 & 1.543 & $3,14 \%$ \\
3 & Denpasar Timur & 48.632 & 1.206 & $2,47 \%$ \\
4 & Denpasar Selatan & 50.689 & 1.711 & $3,37 \%$ \\
\hline & Total & $\mathbf{1 9 8 . 9 2 7}$ & $\mathbf{6 . 1 7 3}$ & $\mathbf{3 , 1 0 \%}$
\end{tabular}

Sumber : Laporan Rekap Surveior Jumantik Kota Denpasar April 2016

Berdasarkan data tersebut dapat dilihat bahwa Kecamatan Denpasar Timur memiliki House Index (HI) paling kecil yaitu $2,47 \%$ bila dibandingkan dengan tiga Kecamatan lainnya. Sedangkan Kecamatan Denpasar Barat memiliki House Index paling tinggi yaitu 3,39\%. Total jumlah rumah yang diperiksa di Kota Denpasar adalah 198.927 rumah dan terdapat 6.173 rumah yang positif jentik dengan presentase rumah positif jentik yaitu $3,10 \%$. 
Tabel 2. Frekuensi Kontainer yang Diperiksa dan Kontainer yang Ditemukan Jentik Di Denpasar (April 2016)

\begin{tabular}{llll}
\hline \multicolumn{1}{c}{ Letak Kontainer } & $\begin{array}{c}\text { Jumlah Kontainer } \\
\text { yang Diperiksa }\end{array}$ & $\begin{array}{c}\text { Jumlah Kontainer } \\
\text { Positif Jentik }\end{array}$ & $\begin{array}{c}\text { Persentase Kontainer } \\
\text { Positif Jentik }\end{array}$ \\
\hline Dalam Rumah & 356.855 & 3.225 & $0.90 \%$ \\
Luar Rumah & 143.675 & 3.922 & $2,73 \%$ \\
& & & \\
\hline Total & $\mathbf{5 0 0 . 5 3 0}$ & $\mathbf{7 . 1 4 7}$ & $\mathbf{1 , 4 3 \%}$ \\
\hline
\end{tabular}

Sumber : Laporan Rekap Surveior Jumantik Kota Denpasar April 2016

Berdasarkan data diatas dapat dilihat bahwa persentase kontainer positif jentik atau Container index (CI) diluar ruangan lebih tinggi daripada didalam ruangan rumah yaitu $2,73 \%$. Sedangkan CI didalam rumah

Tabel 3. Angka Indikator Jentik (\%) yaitu $0,90 \%$. Sehingga total CI kota Denpasar pada bulan April 2016 adalah $1,43 \%$.

\begin{tabular}{lccc}
\hline Kecamatan & House Index & Container Index (CI) & Angka Bebas Jentik \\
& $(\mathrm{HI})$ & & $(\mathrm{ABJ})$ \\
\hline Denpasar Barat & $3,39 \%$ & $1,30 \%$ & $96,60 \%$ \\
Denpasar Utara & $3,14 \%$ & $1,50 \%$ & $96,86 \%$ \\
Denpasar Timur & $2,47 \%$ & $1,11 \%$ & $97,52 \%$ \\
Denpasar Selatan & $3,37 \%$ & $2,39 \%$ & $96,62 \%$ \\
\hline Total & $\mathbf{3 , 1 0 \%}$ & $\mathbf{1 , 5 6 \%}$ & $\mathbf{9 6 , 9 0 \%}$ \\
\hline
\end{tabular}

Sumber : Laporan Rekap Surveior Jumantik Kota Denpasar April 2016

Berdasarkan tabel diatas dapat dilihat bahwa Kecamatan Denpasar Barat memiliki nilai HI tertinggi yaitu 3,39\%. Nilai CI tertinggi terdapat pada Kecamatan Selatan. Sedangkan ABJ tertinggi terdapat di
Kecamatan Denpasar Timur. Secara keseluruhan berturut-turut nilai $\mathrm{HI}, \mathrm{CI}$ dan ABJ kota Denpasar yaitu 3,10\%, 1,56\%, dan $96,90 \%$. 
Uji kerentanan nyamuk aedes sp terhadap fogging insektisida melathion 5\% dengan perbandingan 1 liter melathion: 20 liter solar. Fogging dilakukan pada pukul 07.00 Wita di jalan Palapa IV Blok B. Setelah dilakukan fogging akan dilakukan 2 kali pengamatan yaitu 1 jam pertama setelah fogging dan 24 jam setelah fogging.

Tabel 4. Pengamatan pertama 1 Jam setelah dilakukan fogging

Perlakuan

\begin{tabular}{|c|c|c|c|c|c|c|c|c|}
\hline \multirow{5}{*}{ ulangan } & \multicolumn{4}{|c|}{ Melathion $5 \%$} & \multicolumn{4}{|c|}{ Kontrol } \\
\hline & \multicolumn{2}{|c|}{ Di Dalam } & \multicolumn{2}{|c|}{ Di Luar } & \multicolumn{2}{|c|}{ Di Dalam } & \multicolumn{2}{|c|}{ Di Luar } \\
\hline & Jumlah & Kematian & Jumlah & Kematian & Jumlah & Kematian & Jumlah & Kematian \\
\hline & Nyamuk & $(\%)$ & Nyamuk & $(\%)$ & Nyamuk & $(\%)$ & Nyamuk & $(\%)$ \\
\hline & (ekor) & & (ekor) & & (ekor) & & (ekor) & \\
\hline 1 & 25 & $100 \%$ & 25 & $100 \%$ & 25 & $0 \%$ & 25 & $0 \%$ \\
\hline 2 & 25 & $100 \%$ & 25 & $100 \%$ & 25 & $0 \%$ & 25 & $0 \%$ \\
\hline 3 & 25 & $100 \%$ & 25 & $100 \%$ & 25 & $0 \%$ & 25 & $0 \%$ \\
\hline \multicolumn{9}{|c|}{$\begin{array}{l}\text { Berdasarkan tabel diatas dapat dilihat } \\
\text { bahwa rata-rata jumlah nyamuk intervensi } \\
\text { mati. Karena pada nyamuk kontrol tidak } \\
\text { yang mati di dalam dan di luar ruangan ada nyamuk yang mati maka tidak perlu } \\
\text { adalah } 25 \text { ekor pada pengamatan pertama (1 dilakukan koreksi kematian dengan rumus } \\
\text { jam setelah fogging). Sedangkan pada formula abbot. } \\
\text { Tabel 5. Pengamatan Kedua Dilakukan } 24 \text { jam setelah dilakukan fogging }\end{array}$} \\
\hline \multicolumn{9}{|c|}{ Perlakuan } \\
\hline \multirow{5}{*}{ ulangan } & \multicolumn{4}{|c|}{ Melathion $5 \%$} & \multicolumn{4}{|c|}{ Kontrol } \\
\hline & \multicolumn{2}{|c|}{ Di Dalam } & \multicolumn{2}{|c|}{ Di Luar } & \multicolumn{2}{|c|}{ Di Dalam } & \multicolumn{2}{|c|}{ Di Luar } \\
\hline & Jumlah & Kematian & Jumlah & Kematian & Jumlah & Kematian & Jumlah & Kematian \\
\hline & Nyamuk & $(\%)$ & Nyamuk & $(\%)$ & Nyamuk & $(\%)$ & Nyamuk & $(\%)$ \\
\hline & (ekor) & & (ekor) & & (ekor) & & (ekor) & \\
\hline 1 & 25 & $100 \%$ & 25 & $100 \%$ & 25 & $0 \%$ & 25 & $4 \%$ \\
\hline 2 & 25 & $100 \%$ & 25 & $100 \%$ & 25 & $0 \%$ & 25 & $4 \%$ \\
\hline 3 & 25 & $100 \%$ & 25 & $100 \%$ & 25 & $0 \%$ & 25 & $4 \%$ \\
\hline
\end{tabular}


Berdasarkan tabel diatas dapat dilihat bahwa rata-rata jumlah nyamuk intervensi yang mati di dalam dan di luar ruangan adalah 25 ekor pada pengamatan kedua (24 jam setelah fogging). Sedangkan pada nyamuk kontrol terjadi kematian pada nyamuk di luar ruangan yaitu 1 ekor nyamuk. Karena pada nyamuk kontrol hanya terjadi 1 kematian sehingga persentase kematian nyamuk kontrol menjadi $4 \%$, angka tersebut dibawah $5 \%$ maka tidak perlu dilakukan koreksi kematian dengan rumus formula abbot.

\section{DISKUSI}

Penyakit Demam Berdarah Dengue (DBD) masih menjadi masalah kesehatan setiap tahunnya dan selalu memakan korban jiwa. Penyakit ini disebabkan oleh virus dengue yang ditularkan secara langsung oleh nyamuk Aedes sp. melalui gigitan. Untuk menanggulangi kejadian penyakit ini berbagai program telah dilakukan oleh pihak pemerintah mulai dari pemberantasan sarang nyamuk (PSN) hingga melakukan pemeberantasan nyamuk secara kimiawi yaitu dengan melakukan pengasapan menggunakan insektisida (fogging).

Berdasarkan hasil laporan rekap surveior jumantik Kota Denpasar pada bulan April 2016 mengenai index jentik yaitu House Index (HI), Container Index (CI) dan angka bebas jentik (ABJ) menunjukkan angka yang positif atau baik. Dimana secara keseluruhan berturut-turut nilaif $\mathrm{HI}, \mathrm{CI}$ dan ABJ kota Denpasar yaitu 3,10\%, 1,56\%, dan 96,90\%. Menurut WHO dalam tulisan Salim (2011) daerah yang mempunyai nilai HI yang lebih besar dari 5\% pada umumnya merupakan daerah yang rawan atau sensitive untuk kejadian Demam Berdarah Dengue. Hal ini berarti Kota Denpasar bukan merupakan daerah yang rawan untuk terjadinya DBD. Selain nilai HI Denpasar lebih rendah dari 5\% nilai $\mathrm{ABJ}$ kota Denpasar juga tinggi yaitu 96,90\%. Dimana angka tersebut sudah melebihi dari angka yang ditargetkan oleh DEPKES RI yaitu 95\% (Salim. M et al., 2011).

Dalam penelitian ini upaya yang dilakukan dalam mencegah semakin merebaknya kasus demam berdarah dengue yaitu dengan cara melakukan fogging menggunakan insektisida malathion. Melathion merupakan insektisida golongan organofosfat yang dikenal memiliki kemampuan melumpuhkan atau daya bunuh tinggi terhadap serangga. Melathion bekerja sebagai racun perut, racun kontak dan racun inhasi. Selain itu melathion juga merupakan racun saraf yang bekerja dengan cara menghambat kolinestrase yang mengakibatkan serangga mengalami kelumpuhan dan mati (Djojosumarto dalam Sembiring, 2009). Penggunaan insektisida dalam pembasmian nyamuk bagaikan pisau bermata dua artinya pembasmian secara kimiawi dapat memberikan dampak yang menguntungkan sekaligus merugikan. Penggunaan insektisida apabila dilakukan dengan tepat sasaran, tepat dosis, tepat waktu akan dapat memberikan dampak yang baik dan tidak merusak lingkungan. Akan tetapi apabila pengunaan insektisida tidak sesuai dengan aturan yang berlaku dapat mengakibatkan terjadinya resistensi serangga terhadap insektisida. Terjadinya resistensi ini akan mengakibatkan susahnya 
pengendalian nyamuk apabila terjadi ledakan kasus.

Menurut Kemenkes RI (2012) untuk menghindari terjadinya resistensi selain perlu penerapan manajemen aplikasi insektisida yang tepat sasaran, tepat dosis, tepat waktu juga perlu melakukan rotasi penggunaan insektisida. Rotasi penggunaan insektisida perlu dilakukan dalam periode waktu maksimal 2-3 tahun atau 4-6 kali aplikasi. Namun penggantian bisa dipercepat sesuai dengan hasil monitoring status kerentanan vektor.

Hasil uji kerentanan nyamuk Aedes $s p$. terhadap fogging insektisida melathion $5 \%$ dalam penelitian ini untuk waktu paparan melathion selama 60 menit atau 1 jam setelah dilakukan pengasapan (fogging), persentase kematian nyamuk di dalam dan di luar ruangan tidak ada perbedaan yaitu sebesar $100 \%$ dan tidak tejadi kematian pada nyamuk kontrol. Untuk waktu paparan melathion selama 24 jam atau 1 hari setelah dilakukan pengasapan (fogging), presentase kematian nyamuk di dalam dan di luar ruangan tidak ada perbedaan yaitu $100 \%$ mati dan ada kematian 1 ekor nyamuk kontrol di luar ruangan. Tujuan dilakukannya pengamatan kedua yaitu untuk memastikan bahwa nyamuk telah benar-benar mati setelah diberikan perlakuan dan tidak dalam keadaan pingsan. Persentase kematian yang sama setelah pengamatan 1 jam sampai 24 jam menunjukkan bahwa dengan konsentrasi melathion 5\% telah efektif untuk membunuh nyamuk dalam kurun waktu 60 menit.

Hasil penelitian ini sejalan dengan penelitian yang dilakukan oleh Sudariyanto, et al (2007) di Kabupaten Pekalongan yang memperoleh hasil bahwa nyamuk Aedes aegypti masih rentan terhadap melathion dosis 5\% dengan tingkat kematian 100\% dalam waktu 30 menit. Hasil tersebut didukung juga oleh penelitian yang dilakukan oleh Ambarita, et al (2014) di sebelas Kabupaten di Sumatera Selatan yang memperoleh hasil bahwa nyamuk Aedes aegypti masih rentan terhadap melathion dosis 5\% dengan tingkat kematian $100 \%$.

Rentannya nyamuk Aedes sp. terhadap insektisida melathion sangat dipengaruhi oleh cara penggunaan insektisida tersebut. Dimana semakin lama dan semakin sering insektisida tersebut digunakan akan dapat menimbulkan terjadinya resistensi serangga. Penggunaan insektisida melathion di Kota Denpasar sendiri baru mulai diterapkan pada tahun 2014. Selain itu periode penyemprotan nyamuk dengan insektisida melathion juga tidak dilakukan secara terus-menerus oleh Dinas Kesehatan Kota Denpasar, penyemprotan hanya dilakukan pada daerah-daerah tertentu dan pada waktu tertentu yaitu pada saat terjadinya kasus DBD di daerah tersebut sehingga nyamuk jarang terpapar oleh insektisida melathion.

Penelitian lain yang pernah dilakukan di Denpasar oleh Dinas Kesehatan Kota Denpasar pada tahun 2014 yaitu uji kerentanan vektor DBD dengan meggunakan uji impregnated paper melathion $0,8 \%$ di dapatkan hasil bahwa insektisida melathion hanya dapat membunuh 6 ekor nyamuk Aedes sp. dari 75 ekor nyamuk artinya hanya terjadi $8 \%$ kematian nyamuk dan tidak terjadi kematian pada nyamuk kontrol (25 ekor nyamuk). Hal tersebut 
menujukkan nyamuk telah resisten terhadap bahan uji insektisida melathion 0,8\%. Meskipun objek penelitian dalam penelitian tersebut memiliki karakteristik yang sama dengan penelitian ini namun diperoleh hasil yang berbeda. Perbedaan hasil tersebut dapat dikarenakan metode yang digunakan dalam penelitian yang dilakukan oleh Dinas Kesehatan Kota Denpasar tahun 2014 berbeda dengan metode yang diterapkan pada penelitian ini sehingga dosis yang digunakan juga berbeda.

\section{SIMPULAN}

Berdasarkan hasil penelitian uji resistensi nyamuk Aedes sp.terhadap fogging insektisida melathion $5 \%$, peneliti dapat menyimpulkan bahwa nyamuk Aedes sp. di Wilayah Kota Denpasar masih rentan terhadap fogging melathion 5\%. Daya bunuh fogging insektisida melathion 5\% terhadap nyamuk Aedes sp. di wilayah Kota Denpasar secara umum masih efektif. Tidak terdapat perbedaan daya bunuh fogging insektisida melathion 5\% terhadap nyamuk Aedes sp. di dalam rumah dengan di luar rumah.

\section{SARAN}

Saran yang dapat diberikan adalah bagi Dinas Kesehatan untuk lebih megawasi petugas lapangan (fogging) agar tidak terjadi kesalahan konsentrasi insektisida melathion saat diaplikasikan untuk fogging sesuai dengan yang dianjurkan oleh DEPKES RI untuk menghindari terjadinya resistensi vektor terhadap insektisida. Selain itu penggunaan insektisida melathion sebaiknya tidak digunakan secara terus-menerus, apabila ada insektisida lain yang bisa digunakan untuk membasmi vektor sebaiknya diselingi penggunaan insektisida tersebut untuk mencegah terjadinya resistensi.

Bagi masyarakat untuk tidak selalu mengedepankan atau mengharapkan pemberantasan vektor nyamuk secara kimiawi, karena selain dapat menyebabkan resistensi pada vektor juga dapat menyebabkan kerusakan lingkungan dan mengganggu

\section{DAFTAR PUSTAKA}

Ambarita, et al (2014). Tingkat Kerentanan Aedes Agypti (Linn.) Terhadap Melathion Di Provinsi Sumatera Selatan. Buletin Penelitian Kesehatan, 43(2): 97-104.

Bento. P. L. J, et al. (2003). Resistance Of Aedes Aegypti To Organophosphates In Several Municipalities In The State Of Rio De Janeiro And Espírito Santo, Brazil. Am. J. Trop. Med. Hyg., 68(3): 329-333

Dinkes Kota Denpasar. (2015). Cegah Merebaknya Kasus Demam Berdarah Dengue Pemkot Denpasar Lakukan Larvasidasi Dan Fogging Massal. Tersedia:

http://dinkes.denpasarkota.go.id/index .php/baca-berita/10969/CEGAHMEREBAKNYA-KASUS-DEMAMBERDARAH-DENGUE--PEMKOTDENPASAR-LAKUKANLARVASIDASI-DAN-FOGGINGMASSAL- (Diakses: Senin, 28 Desember 2015)

Dinkes Provinsi Bali. (2014). Profil Kesehatan Provinsi Bali Tahun 2014. Denpasar 
Direktorat Jenderal Pengendalian Penyakit dan Penyehatan Lingkungan. (2012). Pedoman Penggunaan Insektisida (Pestisida) Dalam Pengendalian Vektor. Jakarta: Kementerian Kesehatan Republik Indonesia

Direktorat Jenderal Pengendalian Penyakit dan Penyehatan Lingkungan. (2014). Laporan Perjalanan Dinas Monitoring dan Evaluasi Pemetaan Kerentanan Vektor DBD Di Dinkes Kota Denpasar, Provinsi Bali Tgl. 2-7 Desember 2014. Jakarta: Kementerian Kesehatan Republik Indonesia

Kementrian Kesehatan Indonesia. (2015). Demam Berdarah Biasanya Mulai Meningkat di Januari. Tersedia: http://www.depkes.go.id/article/view/ 15011700003/demam-berdarahbiasanya-mulai-meningkat-dijanuari.html (Diakses: Senin, 28 Desember 2015)

Pusat Data dan Surveilans Epidemiologi Kementrian Kesehatan RI. (2010). Demam Berdarah Dengue di Indonesia Tahun 1968-2009. Buletin Jendela Epidemiologi, 2: 1-43

Salim. M, et al. (2011). Efektifitas Melathion Dalam Pengendalian Vektor DBD Dan Uji Kerentanan Larva Aedes Aegypti Terhadap Themephos Di Kota Palembang. Buletin Penelitian Kesehatan. 39(1): 10 - 21.

Sembiring. O. (2009). Efektifitas Beberapa Jenis Insektisida Terhadap Nyamuk Aedes Aegypti (L). Tesis. Universitas Sumatera Utara.

Shinta, Sukowati, Supratman, Fauziah, Asri. (2008). Kerentanan Nyamuk Aedes aegypti di Daerah Khusus Ibu Kota Jakarta dan Bogor Terhadap
Insektisida Melathion dan Lambdacyhathin. Jurnal Ekologi Kesehatan, 7(1) : 722-731.

Sudariyanto, et al (2007). Daya Bunuh Insektisida Melathion Dan Cynoff 25 ULV Terhadap Nyamuk Aedes Agypti Di Kabupaten Pekalongan.

Sunaryo, et al. (2014). Status Resistensi Vektor Demam Berdarah Dengue (Aedes aegypti) Terhadap Melathion 0,8\% Dan Permethrin 0,25\% Di Provinsi Jawa Tengah. Jurnal Ekologi Kesehatan, 13(2): 146 - 152.

Widiarti, et al. (2011). Peta Resistensi Vektor Demam Berdarah Dengue Aedes Aegypti Terhadap Insektisida Kelompok Organofosfat, Karbamat Dan Pyrethroid di Provinsi Jawa Tengah dan Daerah Istimewa Yogyakarta. Bulletin Penelitian Kesehatan, 39(4): $176-189$. 